\title{
Political Institutions and Official Development Assistance in Africa
}

\author{
KELECHI A. KALU ${ }^{* *}$
}

This paper analyzes the domestic and external factors that impede effective use of Official Development Assistance (ODA) for Sub-Saharan Africa (SSA). It argues that while foreign aid, especially ODA to Africa has significantly increased over the years, SSA has become more dependent on foreign assistance, and economically and politically weaker relative to other less developed states in the international system. Furthermore, it argues that reversing the trend of increasing aid and declining economic productivity in Africa will require that foreign aid, except for direct humanitarian assistance in crisis situations, be completely stopped. The paper concludes with policy directions for reforming the African state, and building strong and sustainable political, economic and socio-cultural institutions for promoting effective ODA for SSA.

Keywords: Foreign Aid, ODA, NEPAD, Political Institutions, Leadership, structural conditions, international financial institutions, state reconstitution, governance institutions

* This paper is a revised version of an Invited Keynote Address for the "2008 International Conference: Emerging Donors and New Approaches to Development Cooperation" in Seoul, Korea on December 5, 2008. The author thanks Jiyoung Kim, Gifty Ako-Adounvo, the anonymous reviewers for ISR, and the audience at the presentation for their helpful questions and comments that have improved the quality of the argument. Devyn Kresty Paros provided assistance with preparing the graph and table.

* Professor of African American and African Studies and Director of the Center for African Studies at The Ohio State University, 386D University Hall 230 North Oval Mall, Columbus, OH 43210, United States. Tel.: +1-614-292-0758; Fax: +1-614-292-2293; E-mail: kalu6@humanities.osu.edu 


\section{I . INTRODUCTION}

$\mathrm{E}$

xcept for Eritrea and Ethiopia, contemporary African states were created for and exploited by external entities, and in spite of political independence, these states remain mostly accountable to external actors, such as the United States and the International Financial Institutions, rather than to domestic constituencies. Except for Ethiopia, Rwanda, Burundi, Swaziland and Lesotho, African states' boundaries are arbitrary and defy cartographic logic, even to the Europeans who created these states. By extension, the management of state institutions and government has largely been responsive to external interests - either to the now defunct systemic structure of the Cold War that included ideological alliances in spite of professed non-alignments, structural adjustment policies or to contemporary efforts at combating international terrorism. Since the inception of the imposed external boundaries on the continent, African leaders and peoples have remained in a transitional phase of political development. Consequently, for personal gain and, at times, through sheer incompetence, public officials at the political and economic gates of Africa's relationships with the rest of the world have largely paid more attention to the advice, aid, and command of external actors than to domestic constituencies such as students, women's organizations, healthcare workers, civil servants, entrepreneurs, and indigenous institutions of civil societies. The desire by these domestic constituencies for effective participation in transforming African states has largely been ignored by the state managers in sub-Saharan Africa. The relationship between African leaders and external entities was more pronounced during the Cold War when foreign aid was largely given as a reward to African leaders based on their due diligence in ferreting out so-called communists in their states and regions. Thus, given the nature of existing governance structures and states in Africa, I would argue that to the extent that foreign aid was aimed at sustaining Africa's strong leaders during the cold war, it was successful since such aid had nothing to do with improving economic growth or poverty alleviation. For example, rather than enabling innovative domestic productive economic activities in countries like Zaire, Central Africa Republic, apartheid South Africa, Sudan, Liberia and various other states in Sub-Saharan Africa, foreign aid largely reflected the ideological relationships between African leaders with either the Eastern socialist or Western capitalist agenda. The failure of aid to help create an enabling domestic environment for improved productive economic activities is largely a result of weak institutions that permit an environment where leaders compete for the state as an instrument for private wealth accumulation rather than as a platform for public service. The weakness of the African state remains an intractable legacy of colonialism and the failed project of nation-building following political independence. Indeed, while foreign aid, especially Official Development Assistance (ODA) to Africa has significantly increased over the years as Figure 1 
below shows, African states have become more dependent on foreign assistance, economically poorer, and institutionally and politically weaker relative to other less developed states in the international system. This is especially evident when African states are compared to states like Malaysia, Indonesia, and South Korea. To reverse the trend of increasing aid and declining economic productivity in Africa will require that foreign aid, except for direct humanitarian assistance in crises situations, be completely stopped. Unless Africans reform the African state by building strong and sustainable political, economic and socio-cultural institutions, and focus their efforts at nation-building within the framework of nationalism and competent educational foundations, no amount of ODA is likely to help Sub-Saharan Africans realize sustainable economic growth and an enhanced standard of living. Similarly, without reforming existing global economic and political structures, ODA to African governments maintains existing global inequality and closes access to foreign markets for African goods, especially agricultural products that form the bulk of what Africans can export at this time. And, given that most foreign aid to African states has largely come in the form of commodity transfers, it is imperative that any kind of cooperative effort at making aid effective in Africa take into account the need to reform how aid is packaged to Africa by donors. Furthermore, African governments should engage their citizens directly on what is needed for transformative change in their communities. Indeed, without reforming domestic and external approaches, continuing aid only obstructs the short and long term vision of African leaders with respect to how to deploy competent and effective African human capital to help transform the continent through effective negotiation of existing international rules that undermine transformative change in Sub-Saharan Africa (SSA). In a nutshell, it is not natural resources that constrain African states from effective domestic economic policies to meet their economic and political needs but rather the lack of political will on the part of the leaders and a general (perhaps rational) decision on the part of the citizens to essentially refuse to die in the name of states that owe them everything and yet deliver nothing. The result is excessive dependence on the goodwill of the donor communities whose ODA, largely in the form of commodity transfers, end up in the donor country's economy either as administrative and technical services while most of the balance ends up in the pockets of corrupt public officials. Below, using liberal institutionalism as background, I examine how external and domestic structures affect development in $\mathrm{SSA}^{1}$ within the framework of ODA and make policy suggestions for promoting effective ODA for SSA. 


\section{SOURCES OF EXTERNAL DIFFICULTIES FOR EFFECTIVE USE OF ODA IN AFRICA}

The modern state system that the colonialists imposed between 1884 and 1885 created more problems than it solved for Africans. The Western state system in Africa lacked hegemony over its domestic and external structural functions. African states' weakness, especially in relation to states in Europe and North America, was not accidental. The imposed state system in Africa was intended by the colonialists to be used as an extension of the geostrategic and economic projects of Europe. Those states merely served the function of extracting their resources for external interests. The authoritarian control of domestic institutions and citizens was also intended to ensure a passive and non-contestant citizenry in the domain of power, especially economic power, which was the colonialists' main interest in Africa. This domestic absolutism was initially unsuccessful as African nationalists, mostly educated in European schools, began to agitate for independence and control of the economic resources of African states by Africans. However, and unfortunately for African states, while political independence was the outcome of the nationalists' agitation, the core powers of the state that should be a basis for building nationalism, economic growth and a stable political system were subverted by Cold War politics. Rather than political independence, each African state was transitioned into dependency on either a socialist or capitalist ideological camp-even as most claimed to be non-aligned. That outcome was welcomed by Africa's former colonialists who wanted to help maintain stability in the continent by propounding a modernization framework that was supposed to lead African states toward a free market economic growth and a liberal political system consistent with assumed practices in the West. That approach stunted and subverted most efforts at political pluralism and innovative economic ideas. And, frequently, rather than interpreting counter arguments as unwelcome direct challenges to their often embellished and borrowed ideas, they saw them as personal attacks and challenges to the leader's authority. The result was the enthronement of power hungry politicians and military autocrats, one-party or military dictatorships in the name of political stability that worked to ensure ideological congruence with foreign allies and the silencing of indigenous development ideas and policies. While the Cold War lasted, and except for Eritrea, efforts at secession that would have redressed the arbitrary state borders or at least engaged African leaders to reconsider the notion of inclusive nation building were quashed. As the domestic, regional and external policies aimed at maintaining Africa's colonial boundaries led to contrived stability of states in Africa, they also resulted in huge businesses in arms shipments to African governments, ensuring that intervention by the socialist camp resulted in counter intervention by the capitalist camp. Consequently, what could be termed the first generation of aid to African states was either 
(a) mostly aid for the interest of arms manufacturers in collaboration with foreign governments rather than for poverty alleviation and economic growth for Africans or, (b) largely loans from the International Monetary Fund with constraints for sub-Saharan Africa governments' capacity for policy autonomy. None of these augured well for a continent in need of economic growth, political stability and inclusive governance (Oliver 1991, 231).

Although the cold-war-derived modernization framework failed in Africa, its end has resulted in (a) Western industrialized countries shifting their interests elsewhere while leaving the economic exploitation of Africa to extractive resource transnational corporations which have (b) resurrected problems of governance, nation building, politicized ethnicity and civil wars. But, an important question that needs clarification is whether the imposed Western state system (a structural condition) or governance (an institutional and therefore leadership condition) or both should remain the platform for more ODA thereby exacerbating African states' weakness, poor economic performance, institutional and infrastructural decay and external exploitation/marginalization of the continent. Indeed, the continuing tendency to rely on external goodwill as solution to the problems emanating from the externally imposed state system in Africa only exacerbate state weakness as evidenced in Zimbabwe under Robert Mugabe and Nigeria under Olusegun Obasanjo. The argument above is not a call for isolating Africa from the international system either on the basis of foreign aid or humanitarian assistance; rather, it suggests a closer examination of the intersection between external and domestic challenges for effective use of ODA in Africa.

Analytically, to the extent that the modern state needs revenues for its existence, it cannot exist without the modern global economy characterized by freedom of action for transnational corporations whose foreign direct investment is a necessary external component to Africa's domestic resource development. Also, to the extent that the modern state in Africa is ineffective in protecting proprietary and physical rights of its citizens and corporations, the impact of ODA will tend to be negative in reducing poverty in the existing state structures because the managers of state institutions and resources remain accountable to external governments and intergovernmental organizations in their economic policies and actions. Furthermore, without the capacity of government to protect citizens or corporations, African states and citizens remain vulnerable to external market and political conditions as is evident in the vicissitudes of currency and interest rates fluctuations that impact African economies. In this regard, African nationals are also directly affected by security policies which mandate extra security searches of Africans at European airports or the spraying of insecticides before airplanes take-off from African airports. Such policies protect major states' citizens traveling in and out of African states at the expense of African nationals. Without internationally recognized forms of legitimate authority and influence that serve general rather than class interests African states cannot efficiently protect proprietary 
and physical rights of their citizens. States whose public policies are based on autochthonous ideas will tend to effectively assert sovereign authority to use ODA effectively as well as mediate the negative external impacts of other states and economies on their citizens. To the extent that imposed colonial state structures with "absolutist and arbitrary powers" (Ake 1996, 1-6) remain the mode of human socio-political organization in post-independence Africa, evacuating Africa's resources to serve the interests of ex-colonial and neocolonial states and institutions will remain an impediment to productive and progressive development in the continent.

As Herman Schwartz $(2000,1)$ argues, "the states selectively create and enforce the property rights that maintain markets; property rights sustain the accumulation of capital and growth of incomes that create the regular and substantial sources of revenues that sustain states." In that respect, understanding how the modern African state which emerged alongside modern markets with their political and economic constraints in the international system derived from European social formations were imposed on Africa will be helpful in evaluating the continent's inability to catch up with other regions in spite of hundreds of billions in ODA to Africa since the 1960s. I argue that the impact of the global political economy on African states are best understood by the impact that the system has on African citizens than on the abstract character of contemporary states; especially since the goal of ODA is to 'help' Africa develop as well as reduce (if not end) poverty.

\section{THE STRUCTURE OF CONIEMPORARY GLOBAL POLITICAL EOONOMY}

Sanford Ungar $(1985,5)$ writes that "certain events in the life of a nation and of a people are almost impossible to forget; they embody the hopes and fears and other intense emotions, and eventually they become symbols of a mood or a moment in history." Especially, for sub-Saharan Africans, the major events - political and economic - are collective in nature. They include the transatlantic slave trade, colonization, disabling socially constructed racial categories of blackness and whiteness, conscription to fight European Wars and structural adjustment policies. All these moments, ideas and events have one thing in common - they are all externally initiated. Consequently, although Africa's problems are not entirely external in nature, productive analysis of the extent to which the existing global political economy, a creation of Western leaders and states, ${ }^{2}$ impact on the governments and peoples of sub-Saharan Africa and their capacity for sustainable development has to be part of the analytical picture. Thus, given this paper's argument that ODA has largely failed to achieve its objectives because of poor governance and governmental institutions in SSA, it is important to also articulate how existing external institutional structures 
combine with the region's weak domestic institutions to impact public policy.

In that regard, while the contemporary state has not always existed as an organizing structure for social relations among peoples, individuals have always had impact on socio-political relations that seek influence over other individuals within institutions and states. The Treaty at Westphalia in 1648 codified the instrumental and institutional forms of contemporary states to settle the proprietary and physical conflicts between the Catholics and the Protestants - a conflict that dates back to the papacy of Pope Gregory VII in 1122. In that respect, states were created to specifically enhance and advance the economic wealth of citizens as well as protect their physical security. Consequently, understanding the nature and/or structure of contemporary global economic system is ipso facto an enquiry into the nature and structure of states and how they accomplish wealth-creation functions. The origin and intended function of the contemporary state system "is best understood as a set of evolving institutions, with the evolutionary process having been set in motion as early as 1122 by the Concordat of Worms" (Bueno de Mesquita 2000, 350). According to Bueno de Mesquita, the reformist Pope Gregory VII (1073-1085) sought to transfer the right of appointment of bishops by kings to popes as a way to circumvent the sale of bishopric appointments by kings to the highest bidder. The struggle over who should appoint the bishops centered on the benefits that accrued from such privilege, which was resolved by the Concordat of Worms whereby papal nomination of bishops would lead to the bishops' elections with the consent of the kings.

This evolutionary process from feudal aristocracy and the settling of the conflicts - largely over property rights - gave rise to the modern state system. The emergence of the modern state system in the $17^{\text {th }}$ century necessitated a preferred economic practice-mercantilism-encouraged protection of European national economies while exploiting those of other states and/or territories. A violent, and sometimes, gradual process that established the authority of legal institutions over individual fiefdoms, the legacies of such institution building remain part of both secular and religious entities globally.

As the economic policy of the mercantilist system sought to increase national wealth by exploiting other frontiers, its administrative political structure became a centralized administration with a standing army for collective defense-an institutional structure. And, although mercantilist policies varied from state to state, the principal objectives were the maximization of the powers of the state and the well being of the citizens (Mayall 1993, 579). Defined as "a doctrine of extensive state regulation of economic activity in the interest of the national economy," (Viner 1948, 1-29) mercantilism advocated both domestic and external state intervention in the market at a time when African states were largely appendages to European states.

For mercantilists, international economic competition parallels states' competi- 
tion for power and security. As a result, a mercantilist will tend to view gains from international economic interaction as having a zero-sum outcome where one state's gain constitutes another's loss. And, in competition, the states with strong institutions often prevail. Overall in a mercantilist economic structure with strong institutions, the interests of the leadership and the state are not always mutually exclusive. This means that the view and practice of the economic and political relations that resulted in the development of the industrialized Western countries simultaneously led to the exploitation and underdevelopment of African states. Irrespective of the type of government in each African state, economic relations between the industrialized countries and African states remain mercantilist in nature as exemplified by the increased attention of the Chinese, Japanese and Americans on access to mineral and non-mineral raw materials in Sub-Saharan Africa.

Economically, Western mercantilist practice viewed Africa as a frontier to be efficiently exploited. To that end, and at the Berlin Conference, Europeans resolved some inter-European conflicts by arbitrarily dividing up the continent of Africa using the familiar (to Europeans) Concordat of Worms (1122) and the Treaty of Westphalia (1648) that was used to resolve earlier issues of property rights in Europe. Indeed, European partition of Africa in 1884-1885 based on their epistemological conception of property rights is an excellent example of state corruption on a scale much larger than existing forms of corruption in various African states. With respect to Africa, mercantilism was the substantive mode of economic and political relations between European states and the continent until the end of World War II. Within fifteen years of political independence, majority of SSA states were under the debt-managed rescheduling agenda of the International Financial Institutions (IFIs). For example, the policy framework dubbed Structural Adjustment Policies (SAP) failed because the IFIs tried to foist free market economic policies on SSA states without attention to the role of politics and political institutions in ensuring effective economic policies, protection of private property rights and implementation of contractual agreements. To that extent, SAP represents a clear case of economic nationalism on the part of the controllers of the international financial agenda that have affected Africa's capacity for economic development. Efforts to implement SAP policies largely resulted in the payment of more interest on loans to external financial institutions without attention to the policy's impact on the healthcare, education and general economic conditions of African citizens.

At the end of the cold war, economic nationalism advocates "call[ed] on their governments to manipulate markets so as to capture special benefits for their nation" (Lairson and Skidmore 1997, 9). Arguably, the logic of states' intervention in the market and its nationalistic components laid the foundation for the intellectual liberal criticism of mercantilist perspectives, which, following the events of September 11, 2001, has reverted back to its mercantilist protectionist stance 
as demonstrated by various U.S. government's efforts to increase tariffs on steel under President W. Bush and unprecedented and continuing levels of government subsidies for farmers, especially since the 2002 budget. Although it has been mostly negated by the global economic crisis induced by failed mortgages, banks and investment firms staffed largely by greedy Wall Street executives, the idea remains that the true road to economic growth and political stability is paved in free market and democracy doctrines ${ }^{3}$ especially for Africans in the international market arena. Indeed, the contemporary global economic crisis has exposed the fact that free market has never been really free; it has squarely put industrial and aid donor governments at the center of running their economies - a manifestation of economic nationalism that Europeans have preached against to African states for decades. However, African states cannot effectively compete against well established states because African political, economic, judicial and social institutions are generally weak.

As Karl Polanyi (1957) asserts, "The road to the free market was opened and kept open by an enormous increase in continuous, centrally organized and controlled interventionism"(140). Clearly, the fact that governments have always interfered in markets has been made more explicit by industrial government economic actions of buying bank stocks and mortgages as well as stimulus packages aimed at rescuing private-market-failed economic policies. Sometimes government involvement includes protecting domestic infant or fledging industries, while at other times they pry open foreign markets to serve particular private economic interests or the general interest of the state. Historically, Max Weber (1968) noted that "[c]apitalism and bureaucracy have found each other and belong intimately together" (141). Weber's notion of the relationship between capitalism and bureaucracy is based on the assumption that economic development and, by extension, foreign economic policies require the existence of a strong bureaucracy whose personnel are recruited on the basis of merit and are insulated from the influence of citizens and politicians, an autonomy that enables the bureaucrats to perform their functions efficiently. Weber's view of a strong bureaucracy is clearly reflected in the gathering of technically well educated individuals within the IMF and the World Bank. However, these officials, although competent are not apolitical representatives of strong and influential states in the international system. According to Weber, a strong state needs to be involved in the decisions affecting foreign economic and domestic policies, especially in an economic environment in which other countries hold a position of advantage on important products.

The foregoing epistemological underpinnings influenced the system of the post World War II international economic structure, which established the United States as a major international economic and political actor in the global system of power; a model consequently adopted by countries like Japan and South Korea in transforming their economies from poverty to wealth. With the marginal 
relevance of the European powers at the end of World War II, emergent global economic and political structures reflect U.S. liberal values in theory, but not in practice. The unfortunate outcome for sub-Saharan Africa is that political independence, economic policies and foreign relations have been occurring on game tables played simultaneously to Africa's disadvantage.

In a nutshell, sub-Saharan African states and their institutions, characterized by general lack of patriotism, especially on the part of political leaders, transparent rules and their implementation, absence of visionary and strategic leadership, lack of committed and patriotic citizens and political opportunism are unlikely to protect the domestic constituencies against external shocks. Consequently, without effective and sustained reform, African states cannot effectively use ODA to transform their economies and enhance the standard of living of the citizens.

\section{COORDINATED DEVELOPMENT APPROACH}

In the 1960s, African states formed the Organization of African Unity to enable the newly independent states to collectively engage the international system dominated by strong industrialized states. The effort failed because the institutional structure similar to the structure of the individual states, lacked effective and competent diplomatic capacity to engage external entities. Even if African states had competent human capital in areas of negotiation, the international rules and strategies were not without constraints as most of the rules of engagement were established by the former colonizers. For example, against the backdrop of Organization of Petroleum Exporting Countries' (OPEC) attempt to change the international economic regime with the call for a New International Economic Order (NIEO) in the 1970s, the Western industrialized states became, consistent with their own interest, quite resilient in their strategies to maintain the existing liberal international system.

In Structural Conflict: The Third World Against Global Liberalism (1985), Stephen Krasner argues that although members of OPEC succeeded in ensuring wealth redistribution from the oil consuming to oil producing states during the first and second oil shocks, collectively the Third World does not have the political or economic capacity to create a new international regime that involves the North. Krasner's argument is premised on the structural realists' claim that foreign policies of states are constrained by the distribution of power in the international system and the position of a given state in that distribution. This view is consistent with the actions the U. S. Government took to shore up the value of the dollar in the 1970s. It cured its domestic economy of high inflation and high unemployment by raising interest rates and essentially saw the transfer of wealth from third world countries, but especially African countries to the West. As Sarah Bracking and Graham Harrison (2008) argue: 
1979 marked a radical change in global economic policy, inaugurated with the 'Volcker Shock' (so called after Paul Volcker, then chairman of the Board of Governors of the Federal Reserve) when the United States suddenly and dramatically raised interest rates, [that] increased the cost of African debt precipitously, since a majority of debt stock was held in dollars. The majority of the newly independent states had been effectively delivered into at least twenty years of indentured labor. From that point on access to finance became a key policing mechanism directed at African populations. ${ }^{4}$

In addition to the effect of externally imposed policy adjustments as a result of the debt overhang, the direct consequence of these externally induced changes to African states' economic condition was reflected in The British Medical Journal opinion in 1999 that:

According to UNICEF, a drop of $10-25 \%$ in average incomes in the $1980 \mathrm{~s} \cdots$ in Africa and Latin America, and a $25 \%$ reduction in spending per capita on health and a $50 \%$ reduction per capita on education in the poorest countries of the world, are mostly attributable to structural adjustment policies. UNICEF has estimated that such adverse effects on progress in developing countries resulted in the deaths of half a million young children - and in just a 12 month period (Ibid).

According to Krasner's structural realist perspective, given that the African states started off with political and economic deficits in the contemporary international system, the marginalization of African states can only be reversed if these countries generate domestic competence that effectively allows them to cope with the existing international system. In this regard, the New Partnership for African Development (NEPAD) would potentially qualify as an effort to create strategies for development that will reverse Africa's marginalization in the international system. But, similar to previous continental and regional efforts such as the Lagos Plan of Action and Lome Conventions, the reliance of the Africa-based NEPAD on external Western revenue mobilization for realizing its goals makes nonsense of the expectations that there is an African renaissance or what some have called Africa's second liberation to realize autochthonous and sustainable development agenda in the continent. ${ }^{5}$

And, as Krasner plausibly argues, the northern industrialized states could also cease to fund international institutions such as the United Nations that provide the forum for the Third World to present a unified front like the NIEO or even make it impossible for Africa to realize the goals of NEPAD by refusing to deal with debt cancellation or new investments. Indeed, the United States 
unilaterally decided to reduce its financial contribution to the World Bank International Development Association in 1984; and other western states promptly followed suit with consequences for access to soft loans from the Bank from poor countries. The power of a strong state like the United States was also evident when the Reagan Administration withdrew the U.S. from UNESCO without regard to the impact of its decision on weak and poor states (see Ali Mazrui in Sanford Ungar, ed. 1985, 182).

Thus, unless African states develop domestic competence and/or disengage from the international system, the choice open to them is to remain marginalized and vulnerable to external shocks because current globalization processes are about portable finance capital, which travels largely to territories where institutionalized economic rules are strong and do not constrain profitable returns to investment. Acceptance of marginalization will also result in African peoples and governments accepting their current status as unsolvable problems requiring external goodwill. However, if African states chose to work within existing international institutions and organizations to help advance their development agenda, then it is imperative that knowledge of the rules and strategies for effective governance and use of economic resources such as ODA be domestically developed as a precondition for participation in the existing international institutions.

Analytically, international institutions provide opportunities for citizens of different countries to meet and discuss various issues in situations where the constraints of different states' objectives would otherwise make such meetings difficult. Because of individual roles in international institutions, neoliberals argue that international regimes tend to result in more cooperation, especially between democratic states, in an otherwise anarchic state system. Thus, neoliberals largely explain international issues within the domestic realm by focusing on the type of government, leadership, public opinion and education that frame the socio-political platform in a given state; to a large extent this view is pertinent to states in Sub-Saharan Africa. Also, neoliberals argue that the international system is evolutionary and that change is possible, especially from conflicts and wars towards national development; hence they often advocate foreign aid as a strategy for poverty alleviation and encouraging economic growth in Africa. They insist that ongoing globalization processes that integrate markets and societies through free trade among states will lead to increased interdependence among states and therefore to global prosperity and peace that mutually benefits everyone.

However, the question that liberal internationalists and most policy analysts do not often ask African leaders is: what incentives exist for reforming and strengthening political and economic institutions in Africa? For the citizens, generally, incentives are opportunities to unleash their entrepreneurial and creative energies to participate in economic growth, political leadership and the development of their various states. It is an opportunity to compete with vigor in the domestic and international marketplace of ideas and influence for individual and collective 
relevance of Africans and their states. But there are no such incentives for the political leaders who are interested largely in maintaining their lifestyles with resources generated from licensing of natural resources exploitations to foreign firms that have no stake in whether a specific government operates with transparency or not. As Ian Taylor $(2005,94)$ argues, there are no incentives for Nigerian, Congolese or for that matter, any other African states' elites to reform the dysfunctional state because whatever gaps in revenue that the state experiences will be filled by resources (ODA) from abroad. The unfortunate aspect of this lack of incentives for reform is that it is consistently rewarded by more foreign aid with blinders on that seem to suggest collusion between the African elites and their external aid collaborators.

Furthermore, internationalists take the existence of 'mutual interests' as a given, and therefore argue that through regime formation, 'mutual interests' can lead to cooperation even under anarchy. Robert Keohane (1984), argues that discord among actors does not have to result in rational egoism. Rather:

If the egoists monitor each other's behavior and if enough of them are willing to cooperate on condition that others cooperate as well, they may be able to adjust their behavior to reduce discord. They may even create and maintain principles, norms, rules and procedures ... as regimes. Properly designed institutions can help egoists to cooperate even in the absence of a hegemonic power $(52) .^{6}$

Keohane's analysis of states' behaviors does not anticipate bad behavior by some donor countries and, specifically African state recipients which results in misuse and abuse of ODA. Thus, the problem with the foregoing is that strong industrialized states mostly cooperate to reduce discord amongst themselves through regional organizations and international institutions. However, where African states are concerned, they also cooperate with African elites by keeping them in power despite failed policies. This was evident with DRC under Mobutu, Nigeria under Abacha, Uganda under Museveni and Angola under Dos Santos, amongst others.

Keohane's analysis suggests that within the structure of the international political economic system, for example, farm subsidies would constitute unilateral withdrawal from cooperation between the European Common Agricultural Policies and the United States. However, such policies actually constitute cooperation because they encourage the crowding out of potential agricultural products from economically and institutionally weak sub-Saharan African states. Similarly, while collaborating industrialized countries could cooperate on matters of military threat, they often do not agree on matters of wealth transfer. This is evident, for example with the slow paced and, in some cases, non-action response to the pledge to increase aid in order to meet the Millennium Development Goals. Theoretically 
(see Waltz 1979, 105-107 and Grieco 1990, 3-19), this cooperation/non-cooperation is possible because states may not be certain whether they 'gain more or less,' if they cooperate. Rather, they fear the probability that if other states gain more, such relative gains may enhance the other states' capacity in ways that might threaten the security of the states that get less, ${ }^{7}$ which is illustrated by the lack of international coordination efforts between the United States and China on Darfur.

According to Robert Jervis (1978), "[b]ecause there are no institutions or authorities that can make and enforce international laws, the policies of cooperation that will bring mutual rewards if others cooperate may bring disaster if they do not" (167). Liberal internationalists contend that international institutions and regimes created by states to mitigate the effect of anarchy,

\begin{abstract}
Serve state objectives not principally by enforcing rules (except when they coordinate rule-enforcement by the strong against the weak, as in the International Monetary Fund-IMF), but by facilitating the making and keeping of agreements through the provision of information and reductions in transaction costs (Baldwin 1993, 274) (Emphasis added).
\end{abstract}

Consequently, African states and citizens need to learn that their governments will cooperate to attain their goals only when the ends-means calculations are favorable. That knowledge also applies to matters affecting ODA where cooperation through foreign aid, especially food aid, to African states is not necessarily altruistic. As a result, donor states will cooperate in the enforcement of existing international rules that privilege their interest against those of African states if the issue-areas involve the adjustment of resources, gains or influence, as is the case with NEPAD in the international system.

Thus, development in Africa requires trade rather than foreign aid because effective trade requires rules and institution-based culture of contract enforcements and implementation. Trade requires citizens' engagement with the technical and abstract nature of their environment to produce marketable and needed products. It creates sustainable employment; it ennobles and empowers citizens to demand more of themselves and their leaders. Trade, more so than foreign aid, engages the mind of the people rather than their bellies. But while reduction in trade barriers can occur, a state that has nothing to trade or lacks the ability to control its markets (e.g. African states) will find no benefits in the free market economic system. Consequently, rethinking, reimagining and reforming various weak and non-responsive governmental institutions, sensitivity to external influence without undermining domestic investment and ideas are necessary for reducing the difficult conditions that inhibit Africa's full participation in the global political economic system. Failure to strengthen various institutional structures to ensure effective citizens' participation in education and economic development will main- 
tain SSA mainly as poverty stricken foreign aid recipients with potentially unsustainable population increase. ${ }^{8}$

Indeed, the interconnectedness that contemporary global political economy portends is one in which the assigned role for Africa is as a continued peripheral status to global centers of power. And, if the continent's population continues its upward slope without requisite increase in educational attainment and entrepreneurial activities that enhance economic growth, such a condition will condemn several generations of Africans to permanent dependence on foreign assistance for basic rather than development needs.

The Human Development Index (HDI), a UNDP (1999, 57) global study shows that 29 of the 35 countries in the 'low human development' category are African states. Overall, this data does not show a significant improvement from 1999 to 2005 (UNDP 2008, 229-232). For its 2007/2008 report, UNDP 2005 data shows that all the 21 countries classified under the category of 'low human development' are Sub-Saharan African states. Also, most states at the bottom half of the 'medium human development' category are African states. In 2007, aggregate data show sub-Saharan Africa's total external debt at $34.2 \%$ of its Gross Domestic Product. And with increasing population most of who fall in the dependent category, a Gross National Income per capita of $\$ 751$ (World Bank 2008, 10) hides the flagrant disparities in the region. For example, while South Africa and Nigeria combine for $54 \%$ of total Sub-Saharan Africa's GDP, only $10.7 \%$ of the South African population lives under $\$ 1$ per day; while $70.8 \%$ of the population in Nigeria lives under $\$ 1$ per day (World Bank African Development Indicators 2008).

Indeed, if $\$ 2$ per day is used as a measure of poverty level in Eastern, Middle and Western regions of Africa, "the percentage of the population living on less than US $\$ 2$ per day was $50 \%$ or greater in every country except Cote d'Ivoire (where it was 49 percent), and 90 percent or higher in Nigeria and Tanzania' (Africa Development Data Sheet). While aggregate GDP for sub-Saharan Africa is approximately $\$ 630$ billion, Central Government revenue is $25 \%$ of that total. While Foreign Direct Investment in the region was a little over $\$ 20$ billion in 2007, sub-Saharan Africa citizens working outside of their state of origin remitted a total of $\$ 2.4$ billion back to the region in 2007 (World Bank 2007). Also, for the region, net aid for 2007 was $\$ 31$ billion which is approximately $5 \%$ of the GDP; and constitutes $28 \%$ of central government expenditure in 2007.

The foregoing aggregate data hides the unsustainable condition that specific African countries find themselves in-excessively depending on foreign development assistance in order to meet their annual budget outlays. For example, Table 1 shows that the net aid as a percentage of government expenditure, which is the nominal total net aid divided by central government expenditure for countries such as Burkina Faso, Chad, Democratic Republic of the Congo, 
Republic of the Congo, Ethiopia, Gambia, Guinea, Madagascar, Malawi, Mozambique, Sierra Leone, Uganda and Zambia depends on ODA for well over $90 \%$ of their government expenditure, with Congo and Sierra Leone well over 200\%. Thus, for most sub-Saharan African states, external influence on their public policies, especially economic policies, will tend to be excessive and unsustainable in the long run. In the short run, these states can also be held hostage by the threat of withdrawal of aid from their benefactors.

Also, Table 1 shows that, except for investments in crude petroleum and mineral rich states such as Nigeria, Sudan and Zambia, net foreign direct investments in many sub-Saharan African states are statistically not significant. This is important because transformative economic development policies have historically relied on investment in infrastructure and manufacturing activities, which foreign direct investment is more suited to help sub-Saharan African states to achieve. But as Table 1 also shows, while net ODA is well over $\$ 30$ billion in sub-Saharan African states, these states owe well over $30 \%$ of their GDP to multilateral and bilateral institutions, mostly to industrialized countries and institutions. Since, for most of the states, foreign direct investment is low compared to total regional population and economic potential (especially in mineral and non-mineral resources), the level of external debt as a percentage of GDP is high, and governments' reliance on ODA is more than $28 \%$ their annual expenditure, it is important to articulate an alternative path for economic development. Such a path must refocus governments and people in sub-Saharan Africa inwards. Without such an approach, the condition observed by Naomi Klein that:

In developing countries carrying heavy debt loads, the Volcker Shock was like a giant Taser gun fired from Washington, sending the developing world into convulsions. Soaring interest rates meant higher interest payments on foreign debts, and often the higher payments could only be made by taking on more loans $\cdots$. It was after the Volcker Shock that Brazil's debt exploded, doubling from $\$ 50$ billion to $\$ 100$ billion in six years. Many African countries, having borrowed heavily in the seventies, found themselves in similar straits: Nigeria's debt in the same short time period went from $\$ 9$ billion to $\$ 29$ billion (Patrick Bond, op. cit.) $\cdots$ will persist.

Indeed, the current condition of aid dependency will continue to undermine genuine efforts by domestic reformers and benevolent external donors and agencies that desire to help African countries transition from a persistent condition of aid consumption to sustainable economic entrepreneurship. In this sense, the reliance of most African states on ODA as a significant aspect of their GDP is troubling. Figure 1 indicates an upward trajectory for overall ODA to Africa, 
especially since 2001. It is unlikely that more aid will lead to changed behavior on the part of public officials without evidence of enhanced living standards for the citizens and reformed governance structures.

As a percentage, Table 1 reveals that ODA contribution to most African states' GDP is in the double digits; and, again this is far less than in other regions. But, if the high debt/service ratio is computed as a percentage of exports of goods and services, it can be seen that the resources that African states receive in the form of ODA are used to help pay interest on outstanding loans to Western institutions; a situation that should raise questions about who really benefits from aid given to sub-Saharan African countries.

\section{FIGURE 1: Total Official Development Assistance for Sub-Saharan Africa, 1990-2006}

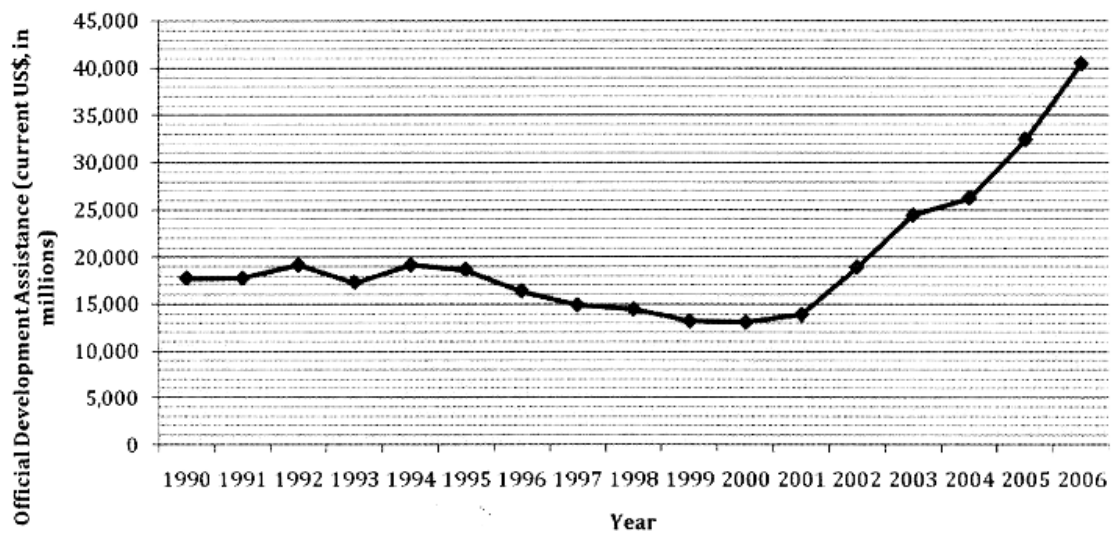

SOURCE of data: The World Bank, 2008.

TABLE 1. Relevant Development Data for Selected African Countries, 2007

\begin{tabular}{c|c|c|c|c|c}
\hline Countries & $\begin{array}{c}\text { Net foreign } \\
\text { direct } \\
\text { investment flows } \\
\text { (\$ millions) }\end{array}$ & $\begin{array}{c}\text { Net aid (\% of } \\
\text { central } \\
\text { government } \\
\text { expenditure) }\end{array}$ & $\begin{array}{c}\text { Net official } \\
\text { development } \\
\text { assistance } \\
\text { (\$ millions) }\end{array}$ & $\begin{array}{c}\text { External debt } \\
\text { as of GDP }\end{array}$ & $\begin{array}{c}\text { Net aid as\% } \\
\text { of GDP }\end{array}$ \\
\hline SSA & 20,038 & $\mathbf{2 8 . 1}$ & 30,686 & 34.2 & 4.9 \\
\hline Benin & 14 & 54.3 & 349 & 43.3 & 8.1 \\
\hline Burkina Faso & 23 & 95.1 & 660 & 35.9 & 11.6 \\
\hline Cameroon & 303 & 23.6 & 414 & 42.4 & 2.5 \\
\hline Central African & 6 & 48.5 & 95 & 74.2 & 7.0 \\
\hline Rep & 124 & 143.1 & 380 & 27.7 & 6.4 \\
\hline Chad & 551 & 310.3 & 1,828 & 149.2 & 25.7 \\
\hline Dem Rep. Congo & 732 & 183.2 & 1,449 & 99.4 & 24.3 \\
\hline Congo, Republic & & & & & \\
\hline
\end{tabular}




\begin{tabular}{c|c|c|c|c|c}
\hline Cote d'Ivoire & 283 & 9.0 & 119 & 66.9 & 0.7 \\
\hline Ethiopia & 150 & 123.7 & 1,937 & 55.0 & 17.0 \\
\hline Gambia, The & 46 & 147.7 & 58 & 145.6 & 12.6 \\
\hline Ghana & 145 & 68.2 & 1,120 & 62.9 & 10.4 \\
\hline Guinea & 9.4 & 97.4 & 182 & 97.6 & 5.5 \\
\hline Madagascar & 86 & 219.2 & 929 & 68.8 & 18.4 \\
\hline Malawi & 26 & 166.2 & 575 & 152 & 27.7 \\
\hline Mozambique & 105 & 188.8 & 1,286 & 75.1 & 18.8 \\
\hline Nigeria & 6,409 & 30.8 & 6,437 & 22.9 & 6.6 \\
\hline Senegal & 101 & 63.3 & 689 & 44.1 & 8.0 \\
\hline Sierre Leone & 27 & 233.2 & 343 & 141.0 & 28.8 \\
\hline Sudan & 2,355 & 39.1 & 1,829 & 66.2 & 6.6 \\
\hline Tanzania & 495 & 70.2 & 1,505 & 61.7 & 12.0 \\
\hline Uganda & 245 & 95.4 & 1,198 & 51.1 & 13.7 \\
\hline Zambia & 380 & 96.8 & 945 & 78.0 & 13.0 \\
\hline
\end{tabular}

SOURCE: The World Bank, The Little Data Book on Africa, 2007. I gratefully acknowledge the assistance of the staff of The World Bank for the relevant data used in constructing the above graph and table.

In light of the foregoing, without urgent attention to autochthonous development ideas based on competent and effective human skills, Africa is likely to remain a consumer of aid and dependent on industrialized Western countries and other aid donor communities. Without the capacity to influence the ideas, policies and outcomes in the international arena, sub-Saharan African states will remain unable to protect their citizens. Strategies that are built on closer relationships between citizens, civil society and government compel the government to be accountable to its domestic constituency. If established in SSA states, such relationships are likely to reduce excessive dependence on ODA which have mostly succeeded in sustaining irresponsible policies and policy makers. Compelling leaders to negotiate with domestic constituencies will enable cooperative and collaborative formulation and implementation of viable economic policies and save resources for the international community as the ODA resources will gradually not be needed because of sustained economic growth at home. For the foregoing to occur, however, there is need to clarify and understand the relevance of specific conceptual issues and substantive strategies that are needed in sub-Saharan Africa. 


\section{INITIATIVES FOR CHANGE IN AFRICA}

\section{Conceptual Issues}

In light of the foregoing analysis, an effective and enduring effort at transformative change in Africa requires that analysts and policy makers grapple with both (1) the conceptual and, (2) the substantive pragmatic issues of state and institutions in Africa as explained below. As previously argued, autochthonous ideas with effective human capacity from sub-Saharan Africa are needed to transcend existing constraints at home and abroad. If ideas for solutions are left to external entities, the status quo is likely to remain, deepening the hopelessness, weakness, incapacity and visionless strategies that African policy makers have pursued so far. And, although African countries are technically in an interdependent relationship with the industrialized Western countries, the lack of autochthonous production facilities based on indigenous ideas and product needs, excessive external debt to the West and inefficient bureaucratic accounting systems often leave many African countries in vulnerable dependence on the West's monetary and fiscal policies that make necessary the use of ODA for "helping" Africa. However and so far, most of the "help" is based on commodity transfers that have failed in terms of poverty alleviation or achieving economic growth in Africa.

Rethinking the structural composition of both the global political economic system and the decision structure of the institutions that implement development assistance policies are likely to result in cooperative and effective use of ODA to assist African states. For example, Western industrialized countries' preferences of monetary over fiscal policies tend to have an inherent negative impact on African countries because such monetary policies directly affect interest and exchange rates that impact Africa's external debts. For example, much of the external debts that African states owe to the West are public debts, which could easily be cancelled by Western governments with little or no impact on Western financial systems, monetary policies or businesses and consumer confidence that tend to drive the economy in the West.

However, the influence of domestic constituencies such as banks and farm lobbies that benefit from close relationships with their governments, foreign aid that subsidize Western raw materials producers and, in turn, undermine domestic production in sub-Saharan Africa (such as cotton in Burkina Faso and Mali) are preferred by non-responsive African leaders as well as their Western benefactors, invalidating serious negotiations of trade rules, especially non-tariff barriers. More ubiquitous is the Common Agricultural Policies of the European Union and the United States government that subsidize their farmers to the tune of almost $\$ 400$ billion annually. This results in the production of cheap foods that flood African markets; killing off domestic commercial agricultural enterprises from southern to western African regions-leaving Africans to depend 
on food aid from Europe and the U.S. Rather than accepting official development assistance, such inherent strategies for wealth accumulation by the West are ubiquitous in the international system. To enable the development of meaningful strategies for economic growth, Africa's decision makers and citizens must think about the structure and set of governance institutions that inform policies in Africa.

How the domestic structure works in the African context requires a clear and unambiguous articulation of the difference between the idea of state and that of governance. Though this sounds commonsensical, that difference is significant to solving Africa's persistent problems. Without concrete visual transformative strategies of the idea of state and governance as currently constituted, the prospect of poverty alleviation based on sustainable economic development policies will continue to elude the continent and elongate its aid dependency. As Kalu (2005) argues, governance is characterized by acceptable norms, institutions and cultures of people, framed around a common language in a territorially delineated space. Structurally, it deals with the specific functions and responsibilities of different machineries of government or institution within a given society or state (174). The issue of governance has become so important that by the 1990 s, the World Bank cognizant of the fact that the economy requires political dimension for its growth, began to support effective and accountable governance as part of the criteria for aid supported by the international financial institutions. For the World Bank (2000), governance is " $\cdots$ the institutional capacity of public organizations to provide the public and other goods demanded by a country's citizens or their representatives in an effective, transparent, impartial, and accountable manner"(48). Effective and transparent governance in both public and private spheres will tend to strengthen political governance, the state and its relations with external entities. The question is how to achieve this level of accountability in sub-Saharan African states.

Rather than huge financial resources, the initial step only requires the use of our imagination. As I have argued elsewhere, 9 the model of the Western state, which is characterized by a set of interconnected institutions whose dynamics are often independent of the institutions of government and civil society remains poorly specified in much scholarly discussion on Africa. For Africa, the concept of state has often been seen as coterminous with government or the ruling class. This misconception evolves from Africa's experience of the colonialist state whose feudalistic structure maintained an absolutist and therefore all-powerful stature in its rule in Africa. The Western state as an "organized aggregate of relatively permanent institutions of governance" (Duvall and Freeman 1981, 106) was neither entrenched as an institutionalized legal order in various African social formations nor was it respected as a framework for unifying the different aspirations of different nationalities.

The colonialist state's brutal efforts to discount primordial identities in Africa succeeded in creating artificial subjects as citizens charged with helping advance 
the materialist interest of the colonists. The outcome remains a wholesale misperception, entrenched at various levels of education in Africa, of the difference between the state and government. Subsequently, with decolonization, the new leaders saw the state in most of Africa as a material object that could be hijacked for personal, class or group interests similar to the colonialists' projection of the state as a feudal entity with an absolutist wealth-generating structure. Essentially, colonial states in Africa were not states in the real sense of that term; rather, what the colonists institutionalized was a familiar (to them) feudalistic structure reminiscent of Europe's early experience at wealth creation through absolutist mercantilist policies like the enclosures in the United Kingdom that subordinated economic production to the interest of the monarchs. In this respect, ODA for much of sub-Saharan African states has failed because it is channeled directly to government officials who see the state as a platform for personal wealth accumulation rather than as a vector for public transformative economic change. Thus, the aid comes in and is mostly redirected either to the personal projects of government officials or simply lodged in private bank accounts in the West and in Asia. Changing the attitude of public officials in sub-Saharan Africa requires changing the nature of the African States through building self-sustaining public institutions that can hold leaders accountable for their miscreant activities. Such understanding requires unambiguous clarification of the concepts of state and government and their mutually reinforcing capacities for advancing the individual and collective interests of citizens in each state. The process will not be easy. It will require a more proactive citizenry than is currently the case on the continent. Also, rather than the politicized identity politics that most of the leaders have relied on to govern since independence, a more nation-state-oriented politics and people-oriented-policies will have to be crafted for transformative change in Africa.

As Naomi Chazan et al., (1999) note, the concept of state is characterized by three important components. First, the decision-making structures, i.e., legislative, executive, political parties and parliaments are responsible for making the decisions that advance the collective interests of the people and therefore the state. The second component of a state is the decision-enforcing institutions such as bureaucracies, parastatal organizations, and security forces. The third and perhaps most important characteristic of state are the decision-mediating institutions - courts, tribunals, and investigatory commissions (38-39). From this viewpoint, the state through its structures, the organization of its people and resources, and how its public policy agendas are set to establish policy prioritics, is essentially an institution of power with definite interests (Ibid). But, as viable as it is, the power of the state is purely conceptual and perceptual. Quite ubiquitous, this power is institutionally and structurally effective in creating spaces for individual and groups' capacities for pursuing different interests that are only checked by the extent such entrepreneurial or exercise of civic rights sustain or challenge 
the unseen, yet present power of the state. Such a state, with legal powers codified in a formal constitutional structure that holds its citizens and institutions accountable for their actions has not been known in the continent of Africa either in its colonial or post-colonial existence.

As evidenced in the series of attempts in 2007 and 2008 by various African leaders (in Nigeria, Zimbabwe, Kenya, Cameroon and elsewhere) to prolong their stay in office by manipulating the constitution to stay beyond their mandated terms of office, most leaders still see the state as private property and thus largely emphasize the vertical at the expense of horizontal nature of power and authority necessary for effective governance and economic productivity. Given that the colonial and post-colonial state structures in Africa were imposed with serious consequences to law, ethical conduct and behavior of government and business leaders, any efforts at transformation and change must redesign existing state boundaries and their constitutions through consultative strategies that seek the participation and input of those whose duties it is to protect and abide by the constitution. Such strategies will work if they enable citizens' participation in politics, build a strong bond on the basis of genuine nationalism and ensure, especially at the civil society level, the vertical nature of state authority to serve as a vector to institutionalize and maintain horizontal powers and authorities in the private sector.

Clearly, if the state and its constitution result from the collective desire of the people, the exercise of state power that leads to contentious outcomes are more likely to be resolved within the state's decision-mediating institutions without resorting to civil war or coup d'etats. Such legitimate outcomes are largely based on the extent the government (this refers to the specific occupants of public offices) is willing to make fair and binding decisions on national and specific issues at all times without overt and/or intentional discrimination on the basis of identifiable criteria such as religion or indigeneity. 10

Public and symbolic demonstrations of the values of citizenship, fairness, justice and equity by public office holders are nation-building strategies that bind different nationalities and citizens to the state and the government. In this respect, and essentially, it is not the state but the government that is responsible for nation-building; it is one of the functions of government to connect the citizens to the state. Since the state is an organization of power and not a neutral concept, it is the responsibility of government to manipulate the organization of citizens and resources to advance the national interest, which at this time for African states is nation-building. From the above, it becomes possible to see that the perceived and much debated failure of post-colonial states in Africa is a failure of government to effectively carry out its nation-building functions of providing a viable state platform for nationalism.

Since the 1960s, African leaders have failed to harness their peoples' energies for transformative change in part because of the availability of foreign aid and 
products that have enabled the leaders to ignore the people and their concerns. Cooperative and collaborative efforts will lead to effective use of ODA for development purposes when Africans and their leaders work together to develop nationalism. Foreign donors who are honest brokers will truly 'help' Africans by giving aid in the form of educational assistance, healthcare facilities, and other forms of aid like vaccination for measles and polio, aid for fighting malaria and river blindness, and other forms of aid that have worked because the people were directly engaged. The aid option that will accelerate improvement in the living standards of the people, and over-all economic development is one that will compel African leaders to negotiate with the people to collaboratively find solutions to domestic development problems. To the extent that African leaders continue to source foreign aid that essentially rewards them for bad behavior, inattention to their domestic constituencies and refusal to participate in the development of the state, the African state will remain in a state of arrested development.

\section{CONCLUSION: SUBSTANTIVE AND PRAGMATIC ISSUES}

Effective development ideas are not lacking in Africa. The African Union $(\mathrm{AU})$ and the New Partnership for Africa's Development (NEPAD) are substantive moves toward ensuring collaborative, integrated and focused economic policies that should lead to increased economic productivity, and, possibly elimination of conflicts in Africa, respect and protection of human and peoples' rights and democratic governance on the continent. Although both the AU and NEPAD concepts are good; they lack effective pragmatic strategies for realizing their stated goals of unified regional/continental development in Africa.

For example, except in regional contexts, African states require visas for interstate travel by citizens. A pragmatic follow-up to the idea of integrated efforts at economic and democratic enhancements in Africa should include an immediate implementation of the free movement of Africans within the continent restrained only by verifiable individual and/or group malfeasance. Such free movement of peoples would also be enhanced by the freedom of individuals to carry out legal business activities in any part of the continent while paying taxes to the government where such business activities are located. An immediate result of this is likely to be an enhanced knowledge, by Africans, of existing resources and opportunities in Africa that should lead to intra-regional/continental trade between and amongst Africans. Such trading activities as a result of ease of mobility and access by Africans is likely to result in a economy of scale for producing exportable goods that will generate export revenue - far greater than existing ODA to SSA. Currently, Africa's share of total global trade is around $2 \%$. Thus, slight improvement in export revenue-provided political and economic 
institutions are strengthened to ensure stability and security - is likely to result in significant improvements in the living standards of the citizenry.

Thus, the focus should be on what individual Africans can contribute to the economic and civic life of the area, region and state in which they choose to locate themselves. Collectively, the question should be: What can individual African states and/or regions produce domestically and more competently compared to other states and regions? The answer to this question should lead to the establishment of companies and industries in identified locations on the basis of low cost of inputs for maximum outputs. Through such intra-continental-focused economic activities, products can be freely moved to continental markets and only goods that are not produced in Africa would be imported. In the short run, and with regard to agricultural productivity, such policies should significantly increase food production given availability of arable lands and low cost inputs in various parts of Africa. In the long run, this strategy should result in increased capacity for domestic revenue mobilization and the eradication of hunger on the continent. Reliance on external aid to buy wheat and other grain, which are easily produced at low cost in Africa, will neither advance the cause of change nor free African states from the external debt trap and food shortage caused by droughts.

The idea of collaborative and cooperative engagement expressed by the AU and NEPAD for the resolution of African problems is good, but their current strategies are not pragmatic. So far, both institutions have been tested and found wanting in Darfur and Zimbabwe where the peer review mechanism failed to ignite the engine of accountability because leaders remain self-absorbed while citizens remain fragmented along ethnic, religious and class lines. Indeed, expecting the West to be responsible for most of the financial resources needed to carry out the agenda articulated in the AU and NEPAD platforms shows African leaders' lack of seriousness to engage in their stated collaborative projects for transformative change.

The suggestions above will be fully economically effective with the erasure of Africa's colonial political/territorial boundaries. Although this idea will be met with internal and external resistance, state reconstitution in Africa will be conceptually and pragmatically realized through such an exercise. Until implemented, its psychological boost to the diplomatic, economic, political and social relations of power between Africa and the rest of the world can only be imagined. Although it is not important to lay out the modalities of such reconstitution at this point, reconstituting African states for more effective and competent governance will create a basis for domestic revenue mobilization for the states. This will require that we think along the lines of creating a minimum of 5 and a maximum of 10 new states from the existing 54 states on the continent. Redrawing the colonial boundaries will enable Africans to more quickly and effectively work collaboratively to deal with catastrophes like famine, conflicts 
and disasters such as flooding and outbreaks of epidemics without waiting for foreign aid for citizens' basic necessities.

In addition to the state boundaries, Africa's educational institutions and infrastructures are also in urgent need of reform and restructuring. Indeed, this is an exercise that should not have to wait for continental restructuring. Those willing to truly help alleviate poverty through ODA can play the most important and direct role by investing in private, yet affordable schools in sub-Saharan African states where most of the tertiary educational institutions have become the structural equivalents of some high schools in the West. To be sure, the current U.S. government program on bigher education initiative in Africa is a good idea; but its impact will be positive to the extent that Africans and their institutions are full partners in thinking through and implementing the relationships between universities in the U.S. and higher education institutions in Africa. Individual states and the donor communities that desire to help should move urgently to create room for students and teachers to think creatively within their environments to produce results and resolve problems to benefit their immediate society.

It is not frivolous to suggest that across the continent, public educational institutions have little or nothing to offer serious and committed scholars and students. Furthermore, in many parts of West and Central Africa, libraries are either non-existent or in shambles. In my conversations with university students in many sub-Saharan African States, but especially in Nigeria and Ghana, very few can identify any serious historical land marks, cultural ideas, or speak either the English language or their indigenous languages competently. Indeed, very few scholars are publishing any serious work on Africa that go beyond polemical gripes with Western-generated theories and methods. Further, with students and scholars not reading about indigenous Africa, foreign ideas which are often transmitted through song lyrics and television programs have become major points of reference. As a consequence of poor educational institutions, many Africans have no chance at transcending poverty and are thus unable to contribute ideas that could enhance their standard of living. In many ways, the inattention to the life of the minds of the citizens is best characterized as a condition of elite misology. Such a disabling life of the mind results in fatalistic tendencies as well as harmful activities like criminal behavior, prostitution and outright scams. Education and poverty alleviation are areas where a missionary-type of commitment to foreign aid or foreign direct investment in infrastructural and educational attainment might be more helpful to African states and their citizens.

Political stability, democratic governance, patriotism and educational reform hold the key to the success of Africa's development objectives as strategies for ending aid dependency. Reconstituting and reforming Africa's educational institutions will also encourage African scholars in all disciplines who are currently contributing to the enhancement of the standards of education of citizens in 
European and American universities, science and technology institutions to return to Africa to participate in relevant educational projects, such as the African Institute for Mathematical Sciences (AIMS) in Cape Town, South Africa. As part of the aid package, the external community can also continue to help by paying skilled indigenous Africans to return to their homelands to apply their skills to changing the lives of their people.

Although such direct involvement will meet with the objection of some, it is better than existing practices of giving aid directly to corrupt leaders who lack vision and consistently ignore their public responsibilities to their citizens. To continue the existing practice of direct aid to governments in Africa encourages and rewards bad behavior by public officials. And because the status quo lacks governance accountability, neglects national infrastructures, engages in opportunistic behavior and suffocation of civil societies, presides over decaying legal, social and political institutions that result in wasteful spending of private and public resources, it condemns the majority of Africans to the equivalent of life sentences. However, with the right mixture of minds and natural resources, African states will be able to develop and market quality products for both domestic use and international competitiveness. And, instead of merely consuming mostly imported products and ideas, African states will become local and overseas investors as well as donor states and exporters of products and ideas to the international community. This preferred option offers states like the United States, South Korea, China, Japan and other industrialized countries an opportunity to work directly with African civil societies and citizens to shift the emphasis from foreign aid dependency toward domestic economic growth.

\section{REFERENCES}

African Population \& Health Research Center. 2008. African Population \& Health Research Center data online. http://www.aphrc.org

Ake, Claude. 1996. Democracy and Development in Africa. Washington, D.C.: The Brookings Institution.

Baldwin, David A. 1993. Neorealism and Neoliberalism: The contemporary Debate. New York: Columbia University Press.

Berber, Benjamin R. 1995. Jihad vs. McWorld. New York: Ballantine Books. Bond, Patrick. 2008. Obama's Economic Advisors: Will Well-Tested Enemies of Africa Prevail? Montbly Review online.

http://www.monthlyreview.org/mrzine/bond121108p.html

Bueno de Mesquita, Bruce. 2000. Principles of International Politics: People's Power, Preferences, and Perceptions. Washington, DC: CQ Press.

Bueno de Mesquita, Bruce. 2000. Political Institutions, Political Survival and

Policy Success in Governing for Prosperity, eds. Bruce Bueno de Mesquita and 
Hilton Root. New Haven: Yale University Press.

Chazan, Naomi, Peter Lewis, Robert Mortimer, Donald Rothchild, and Stephen John Stedman. 1999. Politics and Society in Contemporary Africa, $3^{\text {rd }}$ ed. Boulder: Lynne Rienner Publishers.

Council on Foreign Relations. 2006. More than Humanitarianism: A Strategic U.S. Approach Toward Africa. Independent Task Force Report No. 56. New York: CFR.

Crane, George T. and Abla Amawi. eds. 1991. The Theoretical Evolution of International Political Economy: A Reader. New York: Oxford University Press.

Duvall, Raymond and John R. Freeman. 1981. The State and Dependent Capitalism. International Studies Quarterly 25: 99-118.

Grieco, Joseph M. 1990. Cooperation among Nations: Europe, America, and Non-Tariff barriers to Trade. Ithaca and London: Cornell University Press.

Jervis, Robert. 1978. Cooperation Under the Security Dilemma. World Politics 30(January): 167-214.

Kalu, Kelechi A. 2001. Constitutionalism in Nigeria: A Conceptual Analysis of Ethnicity and Politics. The Nigerian Judicial Review 8: 53-84.

Kalu, Kelechi A. 2005. Global Liberalism and Indigenous Governance in Africa in Globalization and Marginalization: Essays on The Paradoxes of Global and Local Forces, eds.

Olufemi Vaughan, Marcheta Wright and Charles Small. Ibadan, Nigeria: Sefer Press.

Keohane, Robert O. 1984. After Hegemony: Cooperation and Discord in the World Political Economy. Princeton, New Jersey: Princeton University Press.

Krasner, Stephen. 1985. Structural Conflict: The Third World Against Global Liberalism. Berkeley: University of California Press.

Lairson, Thomas D. and David Skidmore. 1997. International Political Economy: The Struggle for Power and Wealth. Fort Worth: Harcourt Brace College Publishers.

Mayall, James. 1993. Mercantilism in The Oxford Companion to Politics of the World, ed. Joel Krieger. New York: Oxford University Press.

Mazrui, Ali A.1985. Uncle Sam's Hearing Aid in Estrangement: America and the World, ed. Sanford J. Ungar. New York: Oxford University Press.

Oliver, Roland A. 1991. The African Experience. London: Weidenfeld \& Nicolson.

Polanyi, Karl. 1957. The Great Transformation. Boston: Beacon Press.

Population Research Bureau. 2008. Africa Population Data Sheet. http://www.prb.org

Schwartz, Herman M. States versus Markets: The Emergence of a Global Economy. New York: St. Martin's Press.

Snyder, Jack. 1991. Myths of Empire: Domestic Politics and International Ambition. Ithaca: Cornell University Press.

UNDP. 2008. Human Development Report 2007/2008. New York: Oxford University Press. 
UNDP. 1999. Human Development Report. New York: Oxford University Press. Ungar, Sanford J. ed. 1985. Estrangement: America and the World. New York: Oxford University Press.

Viner, Jacob. 1948. Power versus Plenty as Objectives of Foreign Policy in the Seventeenth and Eighteenth Centuries. World Politics, 1(1): 1-29.

Waltz, Kenneth N. 1979. Theory of International Politics. New York: Random House.

Weber, Max. 1968. Economy and Society, eds. Guenther Roth and Claus Wittich. New York: Bedminster Press.

World Bank. 2008. Africa Development Indicators. http://web.worldbank.org/Website/external/countries/Africaext/extpub

World Bank. 2008. The Little data Book on Africa 2007. Washington, D.C.: The World Bank. 


\section{ENDNOTES}

1 The decision to examine the effect of ODA on development in SSA is consistent with the economic and political strategies that external actors have used in their economic and political relations with the sub-region. For example, the United States considers the North African region as part of the Middle East and indeed categorizes it in its official policy framework as "Caucasian North Africa," and subsequently treats SSA as if it was one country. Similarly, the emerging dominance of China in the international political economy is taking a similar route of approaching sub-Saharan African states as if they were one country. For example, the Forum on China and Africa, 2000, brought 48 African Heads of States to Beijing-even as its investments are country specific - to engage in a one-stop resource and investment shopping in Africa. Indeed, countries like South Korea and India are also shaping their policies toward SSA as if it is a single country. Consequently, and contrary to the concern expressed by one reviewer, it makes sense to examine Africa's problems as a collective, especially where the economic and political issues remain identical; to do otherwise amounts to the old strategy of "divide and conquer".

2 This section relies on my chapter titled "The Global Political Economy and the State in Africa," an invited chapter for a Ford Foundation study on The State in Africa: Beyond False Starts," George Kieh and Pita Agbese, editors (Forthcoming).

${ }^{3}$ In a news clip on (Ghana Television, June $13^{\text {th }}, 2002$ ) investments and development in Africa and the recently concluded meeting of stakeholders in Germany, a U.S. Information Officer, Mary Daunsbach, reminded Ghanaians that U.S. Trade bill does not distort free trade or U.S. obligation in the World Trade Organization (WTO). She acknowledged that the U.S. government grants subsidies to farmers, but that it is much smaller than subsidies by any other industrialized country. The issue here is that the small farm subsidy of $\$ 180$ billion over 10 years is not only government intrusion into the market, but it is a deliberate mercantilist policy at the expense of African countries whose main exports are agricultural products that continue to be stifled by restrictive industrialized countries' policies.

${ }^{4}$ Cited in Patrick Bond, “Obama's Economic Advisors: Will Well-tested Enemies of Africa Prevail? Montbly Review online http://www.monthlyreview.org/mrzine/bond121108p.html retrieved November 28, 2008.

"For those interested in pursuing this argument further, the core questions are: why has the African Peer Review Mechanism only resulted in the review of essentially 3 out of 53 countries? Why are leaders such as Robert Mugabe and Omar Al-Bashir able to call the shots within the African Union? For some excellent insights on these and other issues regarding the so called African Renaissance, see Ian Taylor, Nepad: Tonvard Africa's Development or Anotber False Start? (Boulder and London: Lynne Rienner Publishers, 2005).

${ }^{6}$ Robert O. Keohane, After Hegemony: Cooperation and Discord in the World Political Economy (Princeton, New Jersey: Princeton University Press, 1984), p. 84. Keohane defines discord "as the situation in which governments regard each others' policies as hindering the attainment of their goals, and hold each other responsible for these constraints" (p. 52). On the other hand, cooperation is dcfined as a situation that allows "intergovernmental cooperation [to] take place when the policies actually followed by one government are regarded by its partners as facilitating realization of their own objectives, as the result of a process of policy coordination" (pp. 51-52).

7 Kenneth Waltz (1979), pp. 105-107. Also, see Joseph M. Grieco (1990), pp. 3-10. Realists and liberals share the view that the fear of cheating impedes cooperation among states. Grieco criticizes liberals for believing that only the fear of cheating inhibits agreements from which both sides would gain. According to Grieco, state " $\mathrm{A}$ " as a "defensive positionalist" may also fear that state "B" may have greater relative gain that could compromise "A's" security.

8 According to the 2008 Population Reference Bureau, Africa's population in mid-2008 is estimated at 967 million with $42 \%$ of that below age 15 . Growing at an annual rate of $2.4 \%$. Africa's population is estimated to reach 1.9 billion by 2050 . See Population Research Bureau website at http://www.prb.org Also, see African Population \& Health Research Center data online at http://www.aphrc.org

9 This section draws from my earlier work on constitutionalism and management of contentious issues in Nigerian politics. See "Constitutionalism in Nigeria: A Conceptual Analysis of Ethnicity and Politics," The Nigerian Juridical Review, Vol. 8, (2000-2001): 53-84.

${ }^{10}$ Much of the problem with governance in Africa will be solved when individual identities are not largely categorized on the bases of indigeneity, gender, class or religion. Such an effort has to be part of a new social and constitutional compact between all nationals such that citizenship is purposefully entrenched as the principal identity in each African state. 